\title{
PENGARUH STRES DAN KONFLIK TERHADAP KINERJA PEGAWAI PADA PT PLN (PERSERO) P3B SUMATERA UPT PEMATANGSIANTAR
}

\author{
Oleh: \\ Ressy Julianti Sibuea \\ S1 Manajemen \\ Darwin Lie, Marisi Butarbutar, Fitria Halim
}

Abstraksi

Tujuan penelitian ini adalah: 1. Untuk mengetahui gambaran stres, konflik dan kinerja pegawai pada PT PLN (Persero) P3B Sumatera UPT Pematangsiantar. 2. Untuk mengetahui pengaruh stres dan konflik terhadap kinerja pegawai pada PT PLN (Persero) P3B Sumatera UPT Pematangsiantar baik secara simultan maupun parsial.

Penelitian ini dilakukan dengan menggunakan desain penelitian lapangan dan kepustakaan. Sumber data yang digunakan adalah data primer dan data sekunder. Jenis data yang digunakan adalah data kualitatif dan data kuantitatif yaitu sebanyak 96 responden yaitu pegawai pada PT PLN (Persero) P3B Sumatera UPT Pematangsiantar. Pengumpulan data dilakukan dengan kuesioner, wawancara dan dokumentasi. Teknik analisis yang digunakan ialah regresi linier berganda, koefisien korelasi dan determinasi serta pengujian hipotesis dengan uji $\mathrm{F}$ dan uji t.

Hasil penelitian dapat disimpulkan sebagai berikut: 1 . Tingkat stres pegawai rendah dan konflik yang ada pada PT PLN (Persero) P3B Sumatera UPT Pematangsiantar cukup tinggi serta kinerja pegawai sudah baik. 2. Hasil analisis regresi adalah $\hat{Y}=78,456-0,202 X_{1}-0,311 X_{2}$, artinya stres dan konflik berpengaruh negatif terhadap kinerja pegawai. 3. Hasil analisis korelasi diperoleh nilai $r=0,453$ artinya terdapat hubungan yang sedang antara stres dan konflik terhadap kinerja pegawai pada PT PLN (Persero) P3B Sumatera UPT Pematangsiantar. Tinggi rendahnya kinerja pegawai dapat dijelaskan oleh stres dan konflik sebesar $20,6 \%$. 4. Hipotesis penelitian $\mathrm{H}_{0}$ ditolak, artinya stres dan konflik berpengaruh negatif dan signifikan terhadap kinerja pegawai pada PT PLN (Persero) P3B Sumatera UPT Pematangsiantar baik secara simultan maupun parsial.

Adapun saran dari penelitian ini adalah untuk mengelola stres, sebaiknya perusahaan menyediakan fasilitas yang memadai agar tercipta kondisi kerja yang baik bagi para pegawai, dan pimpinan lebih bersikap tegas supaya pegawai mematuhi peraturan perusahaan. Dalam mengelola konflik, sebaiknya para pegawai melakukan persaingan secara sehat untuk meraih prestasi kerja. Dalam mengoptimalkan kinerja, sebaiknya pegawai mengeluarkan semua potensinya dalam merealisasikan tujuan perusahaan, dan pegawai saling sepakat bekerjasama dalam menyelesaikan suatu pekerjaan.

Kata kunci: Stres, Konflik, dan Kinerja Pegawai.

Abstraction

The purpose of this research is: 1 . To determine the description of stress, conflict and employee performance at PT PLN (Persero) P3B Sumatera UPT Pematangsiantar. 2. To determine the influence of stress and conflict to employee performance at the PT PLN (Persero) P3B Sumatera UPT Pematangsiantar either simultaneously or partially.

This research was done by using literature and field research. Source data used are primary data and secondary data. The type of data used quantitative and qualitative data of 96 respondents are employess on PT PLN (Persero) P3B Sumatera UPT Pematangsiantar. Collecting data done by questionraines, interviews and documentations. The analysis technique has done by regression multiple linear, coefficient correlation and determination with testing hypothesis with test $F$ and test $t$.

The result of this research can be summarized as follows: 1. Employee stress levels was low and conflicts that exist at the PT PLN (Persero) P3B Sumatera UPT Pematangsiantar was high enough too and employee performance has been good. 2. The results of regression analysis is $\hat{Y}=78,456$ $0,202 X_{1}-0,311 X_{2}$, meaning stress and conflict has negative influence to employee performance. 3 . The result of analysis correlations $r=0,453$ it's means that there is a relationship between being and stress and conflict to employee performance at PT PLN (Persero) P3B Sumatera UPT Pematangsiantar. It means employee performance can be explamed by $20,6 \%$ by stress and conflict. 4. Hypothesis $H_{0}$ is rejected, it means the stress and conflicts has negative and significant influence to employee performance at the PT PLN (Persero) P3B Sumatera UPT Pematangsiantar either simultaneously or partially.

The suggestion of this research related stress, the company should provide adequate facilities in order to create better working conditions for employees, and the leader need to be firm so the 
employees obey the company regulations. In addressing the conflict, employee should conduct a healthy competition for achievement of work. In optimizing the performance, employee should expend all its potential in realizing the objectives of the company, and the employee mutually agree to cooperate in completing a job.

Keywords: Stress, Conflict and Employee Performance.

\section{A. PENDAHULUAN}

1. Latar Belakang Masalah

PT PLN (Persero) Penyaluran dan Pusat Pengatur Beban (P3B) Sumatera Unit Pelayanan Transmisi (UPT) Pematangsiantar merupakan badan usaha milik negara (BUMN) yang bergerak dalam bidang penyedia tenaga listrik. Di dalam menjalankan kegiatan perusahaan PT PLN (Persero) P3B Sumatera UPT Pematangsiantar memiliki berbagai macam kendala yang berhubungan dengan kinerja para pegawainya.

Kinerja merupakan hasil kerja yang dapat dicapai pegawai, sesuai dengan tugas dan wewenang masing-masing dalam rangka mencapai tujuan perusahaan. Kinerja pegawai pada PT PLN (Persero) P3B Sumatera UPT Pematangsiantar dinilai dari dimensi specific, measurable, achievable, realistic, dan timebound. Berdasarkan hasil wawancara pada Bagian Umum di PT PLN (Persero) P3B Sumatera UPT Pematangsiantar bahwa secara umum dari 126 pegawai terdapat kinerja pegawai yang sangat baik $33 \%$, baik $48 \%$, cukup baik $18 \%$ dan tidak baik $1 \%$. Berdasarkan fenomena tersebut diketahui bahwa kinerja yang dominan rendah adalah terjadi pada dimensi measurable, hal ini dapat terlihat dari banyaknya jumlah beban kerja yang diberikan kepada pegawai sehingga mengakibatkan ukuran hasil kerja dan tingkat target kerja yang dicapai oleh pegawai kurang optimal. Selain itu pengetahuan mengenai pekerjaan dan keterampilan yang menyangkut pekerjaannya masih relatif sempit.

Salah satu faktor yang diindikasikan dapat mempengaruhi kinerja pegawai adalah stres. Stres harus dikelola dengan baik agar stres dapat diatasi dan diharapkan dapat meningkatkan kinerja pegawai. Stres kerja pegawai pada PT PLN (Persero) P3B Sumatera UPT Pematangsiantar dapat dilihat dari fenomena stres yang sering terjadi pada PT PLN (Persero) P3B Sumatera UPT Pematangsiantar dapat dilihat dari dimensi tuntutan tugas yang terlalu berat seperti dalam melakukan pekerjaan pegawai mendapat tugas ke luar kota, sementara masih ada tugas yang belum terselesaikan di kantor, minimnya pendidikan dan pelatihan kompetensi pegawai dalam menyelesaikan beban tugas yang diberikan, dan tekanan tugas dari atasan juga menambah beban pekerjaan pegawai.
Selain faktor stres, konflik juga diindikasikan sebagai hal yang dapat mempengaruhi kinerja pegawai di PT PLN (Persero) P3B Sumatera UPT Pematangsiantar. Jenis konflik yang terjadi pada PT PLN (Persero) P3B Sumatera UPT Pematangsiantar dapat dilihat melalui dimensi konflik fungsional dan konflik disfungsional. Adapun fenomena konflik fungsional yang terjadi pada PT PLN (Persero) P3B Sumatera UPT Pematangsiantar yaitu para pegawai saling bersaing secara sehat untuk berprestasi di tempat kerja demi meraih sebuah jabatan. Sementara fenomena konflik disfungsional yang terjadi pada PT PLN (Persero) P3B Sumatera UPT Pematangsiantar meliputi konflik antara rekan sekerja yaitu kurang saling mendukung dalam mengerjakan pekerjaan secara team.

\section{Rumusan Masalah}

a. Bagaimana gambaran stres, konflik dan kinerja pegawai pada PT PLN (Persero) P3B Sumatera UPT Pematangsiantar.

b. Bagaimana pengaruh stres dan konflik terhadap kinerja pegawai pada PT PLN (Persero) P3B Sumatera UPT Pematangsiantar baik secara simultan maupun parsial.

\section{Tujuan Penelitian}

a. Untuk mengetahui gambaran stres, konflik dan kinerja pegawai pada PT PLN (Persero) P3B Sumatera UPT Pematangsiantar.

b. Untuk mengetahui pengaruh stres dan konflik terhadap kinerja pegawai pada PT PLN (Persero) P3B Sumatera UPT Pematangsiantar baik secara simultan dan parsial.

\section{Metode Penelitian}

Objek penelitian adalah PT PLN (Persero) P3B Sumatera UPT Pematangsiantar yang terletak di Jalan Sangnawaluh KM 4.5 Pematangsiantar - 21151. Telp (0622) 7550874. Faximile (0622) 7552223. Populasi adalah pegawai kantor PT PLN (Persero) P3B Sumatera UPT Pematangsiantar sebanyak 126 pegawai tetap. Berdasarkan perhitungan perhitungan dengan rumus Slovin, jumlah sampel yang digunakan adalah 96 pegawai.

Desain penelitian adalah Penelitian Kepustakaan (Library Research) dan Penelitian Lapangan (Field Research). Teknik pengumpulan data berupa Kuesioner, Wawancara dan Dokumentasi. Jenis data yang 
adalah jenis data kualitatif dan data kuantitatif. Hasil data yang diperoleh dari lapangan akan dianalisis secara deskriptif baik bersifat kualitatif dan kuantitatif.

\section{B. LANDASAN TEORI}

1. Manajemen Sumber Daya Manusia

Menurut Mondy (2008:4), manajemen sumber daya manusia adalah pemanfaatan sejumah individu untuk mencapai tujuan-tujuan organisasi. Sedangkan menurut Dessler (2007:2), manajemen sumber daya manusia adalah kebijakan dan cara-cara yang dipraktekkan dan berhubungan dengan pemberdayaan manusia atau aspek-aspek sumber daya manusia dari sebuah penilaian. Berdasarkan pendapat para ahli di atas, penulis menyimpulkan bahwa manajemen sumber daya manusia adalah suatu kebijakan organisasi dalam pemanfaatan sejumlah individu untuk mengatasi tiap-tiap masalah yang terjadi di dalam organisasi.

\section{Stres Kerja}

Menurut Luthans (2006:794), stres kerja adalah respon adaptif terhadap situasi eksternal yang menghasilkan penyimpangan fisik, psikologis, dan atau perilaku pada anggota organisasi. Sedangkan menurut Robbins (2006:793), stres kerja adalah adalah kondisi dinamik didalam bekerja yang di dalamnya individu menghadapi peluang, kendala (constraints), atau tuntutan (demands) yang terkait dengan apa yang sangat diinginkannya dan yang hasilnya dipersepsikan sebagai tidak pasti tetapi penting. Berdasarkan pengertian di atas penulis menyimpulkan bahwa stres merupakan suatu kondisi yang disebabkan adannya ketidaksesuaian antara situasi yang tidak diinginkan dengan keadaan biologis, psikologis atau sistem sosial individu.

Menurut Robbins (2006:796), faktor-faktor organisasi yang dapat dipakai untuk mengukur stres kerja seorang karyawan adalah: tuntutan tugas, tuntutan peran, tuntutan antarpribadi, struktur organisasi, dan kepemimpinan organisasi.

\section{Konflik}

Menurut Robbins (2008:173), sebuah proses yang dimulai ketika satu pihak memiliki persepsi bahwa pihak lain mempengaruhi secara negatif, sesuatu yang menjadi kepedulian atau kepentingan pihak pertama. Menurut Wahyudi (2011:17), menyatakan bahwa konflik adalah perselisihan, pertentangan antara dua orang atau dua kelompok dimana perbuatan yang satu berlawanan dengan yang lainnya sehingga salah satu atau keduanya saling terganggu. Sedangkan menurut Luthans (2006:449), konflik merupakan kejadian yang terjadi pada intra individu yang menyebabkan frustasi, kelainan tujuan dan perbedaan peranan. Berdasarkan pengertian para ahli, dapat disimpulkan bahwa konflik adalah suatu masalah sosial yang timbul karena adanya perbedaan pandangan diantara pihak-pihak individu dalam pencapaian tujuan perusahaan.

Berdasarkan jenisnya, Robbins dan Timothy (2008:175), membagi konflik menjadi dua macam, yaitu konflik fungsional (functional conflict), dan konflik disfungsional (dysfunctional conflict).

\section{Kinerja}

Menurut Mathis dan John (2006:113), kinerja adalah suatu hasil kerja yang dicapai seseorang dalam melaksanakan tugas-tugas yang dibebankan kepadanya yang didasarkan atas kecakapan, pengalaman,dan kesungguhan serta waktu. Menurut Mangkunegara (2001:67), kinerja adalah hasil kerja secara kualitas dan kuantitas yang dicapai oleh seseorang pegawai dalam melaksanakan tugasnya sesuai dengan tanggung jawab yang diberikan kepadanya. Berdasarkan uraian di atas, penulis menyimpulkan bahwa kinerja merupakan hasil atau tingkat keberhasilan seseorang secara keseluruhan selama periode tertentu dalam melaksanakan tugas.

Menurut Keputusan Direksi PT PLN (Persero) No. 1504. K/DIR/2011, indikator kinerja pada PT PLN (Persero) P3B Sumatera UPT Pematangsiantar adalah: Specific, Measurable, Achievable, Realistic, dan Timebound.

\section{PEMBAHASAN}

\section{Analisa}

\section{a. Deskriptif Kualitatif}

Analisis Analisis deskriptif kualitatif dimaksudkan untuk mendapatkan gambaran atau deskripsi mengenai tanggapan dari pegawai mengenai Pengaruh Stres dan Konflik terhadap Kinerja Pegawai pada PT PLN (Persero) P3B Sumatera UPT Pematangsiantar. Adapun penetapan kriteria nilai rata-rata jawaban dari responden tersebut dimasukan ke dalam kelas-kelas interval sebagai berikut: Interval Kelas $=$ Nilai Tertinggi - Nilai Terendah

$$
\begin{aligned}
& =\frac{5-1}{5} \\
& =\frac{4}{5} \\
& =0,8
\end{aligned}
$$

Dari rumus diatas dapat diperoleh interval kelas 0,8 sehingga berlaku ketentuan kategori dengan hasil berikut:

Tabel 1

Nilai Interval dan Kategori Jawaban Responden. 


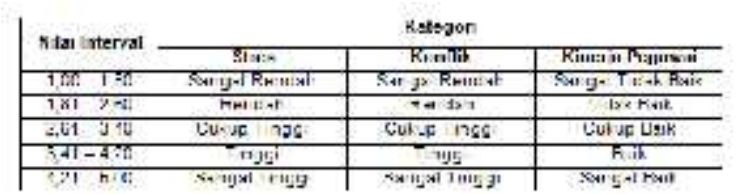

Sumber : hasil pengolahan data

\section{1) Gambaran Stres Pada PT PLN (Persero) P3B Sumatera UPT Pematangsiantar}

Dari hasil analisa, dimensi tuntutan tugas pada indikator pekerjaan individu berada pada rata-rata 2,51 dengan kriteria jawaban rendah, hal ini disebabkan pegawai dapat menyelesaikan tugas individu dengan baik. Pada indikator kondisi kerja berada pada ratarata 2,58 responden memberikan kriteria jawaban rendah, hal ini disebabkan perusahaan memberikan fasilitas kerja sehingga kondisi kerja mendukung bagi para pegawai. Pada indikator tata letak kerja fisik berada pada ratarata 2,64 responden memberikan kriteria jawaban cukup tinggi, hal ini disebabkan lokasi ruangan kerja pegawai yang disediakan oleh perusahaan masih belum teratur dan kurangnya ruang gerak bagi para pegawai.

Untuk dimensi tuntutan peran pada indikator peran ganda berada pada rata-rata 2,60 dengan kriteria rendah, hal ini disebabkan pegawai mampu menyelesaikan tugas lain diluar pekerjaan utamanya. Sedangkan pada indikator tingkat pemahaman pegawai memiliki nilai rata-rata 2,53 dengan kriteria jawaban rendah, hal ini disebabkan pegawai telah memahami pekerjaan yang akan dilakukannya. Kemudian pada indikator kesanggupan menyelesaikan pekerjaan yang kurang sesuai dengan kemampuan yang dimiliki berada pada rata-rata 2,57 dengan kriteria rendah, hal ini disebabkan pegawai telah dibekali kemampuan yang baik untuk menyelesaikan tanggungjawabnya dalam bekerja.

Untuk dimensi tuntutan antar pribadi pada indikator dukungan sosial antar pegawai di tempat kerja berada pada rata-rata 2,63 dengan kriteria cukup tinggi, hal ini disebabkan kurangnya sikap kepedulian antar sesama pegawai. Sementara pada indikator memaham kepribadian buruk rekan kerja berada pada rata-rata 2,47 dengan kriteria rendah, hal ini disebabkan setiap pegawai telah mengetahui kepribadian buruk rekan kerjanya. Sementara pada indikator kemampuan perusahaan memberikan kebutuhan sosial berada pada rata-rata 2,52 dengan kriteria rendah, hal ini disebabkan perusahaan telah memberikan jaminan sosial kepada seluruh pegawai.

Untuk dimensi struktur organisasi pada indikator tingkat diferensiasi struktur organisas pada perusahaan responden memberikan ratarata jawaban 2,46 dengan kriteria rendah, hal ini disebabkan para pegawai mampu menjalankan perannya dengan baik terkait dengan struktur organisasi yang ada. Pada indikator tingkat aturan dan peraturan responden memberikan dengan nilai rata-rata 2,58 dengan kriteria rendah, hal ini disebabkan para pegawai mematuhi peraturan perusahaan dalam bekerja. Pada indikator sistem pengambilan keputusan yang ada di tempat kerja berada pada rata-rata 2,57 dengan kriteria rendah, hal ini disebabkan perusahaan memiliki sistem pengambilan keputusan yang bersifat terbuka dan menerima masukan atau pendapat dari setiap pegawai.

Selanjutnya untuk dimensi kepemimpinan pada indikator gaya kepemimpinan pada PT PLN (Persero) P3B Sumatera UPT Pematangsiantar responden merespon dengan rata-rata 2,58 dengan kriteria rendah, hal ini disebabkan pimpinan mampu memotivasi para pegawai melalui gaya kepemimpinannya. Selanjutnya pada indikator kepedulian terhadap pegawai baru di tempat kerja diperoleh dengan nilai rata-rata 2,61 dengan kriteria cukup tinggi, hal ini disebabkan pegawai lama belum dapat bersosialisasi dengan pegawai baru secara baik. Untuk indikator kemampuan dalam memimpin rapat saat diperlukan berada pada nilai rata-rata 2,68 dengan kriteria cukup tinggi, hal ini disebabkan para pegawai belum mampu menggantikan pimpinan dalam memimpin rapat.

Secara keseluruhan dapat dilihat bahwa rekapitulasi jawaban responden mengenai stres berada pada rata-rata 2,56 dengan kriteria jawaban rendah. Kemudian, nilai rata-rata tertinggi sebesar 2,68 pada dimensi kepemimpinan dengan indikator kemampuan dalam memimpin rapat saat diperlukan. Sedangkan nilai rata-rata terendah sebesar 2,46 berada pada dimensi struktur organisasi dengan indikator tingkat penentuan diferensiasi struktur organisasi di tempat kerja.

\section{2) Gambaran Konflik Pada PT PLN (Persero) P3B Sumatera UPT Pematangsiantar}

Dari hasil analisa, dapat dijelaskan untuk dimensi konflik fungsional pada indikator persaingan dalam mencapai prestasi di tempat kerja berada pada rata-rata 2,99 dengan kriteria jawaban cukup tinggi, hal ini disebabkan para pegawai berminat untuk bersaing guna mencapai prestasi di tempat kerja. Pada indikator tingkat kreativitas di tempat kerja berada pada rata-rata 2,92 dengan kriteria jawaban cukup tinggi, hal ini disebabkan pegawai kurang mampu menciptakan ide-ide baru dalam bekerja. Kemudian pada indikator tindakan yang diberikan pegawai dalam melakukan perubahan berada pada rata-rata 2,90 dengan kriteria jawaban cukup tinggi, hal ini disebabkan pegawai belum mampu berinovasi dalam menciptakan perubahan yang lebih baik bagi perusahaan.

Demikian juga pada dimensi konflik disfungsional pada indikator tanggapan anda saat diberikan tugas secara team berada pada 
rata-rata 2,91 dengan kriteria jawaban cukup tinggi, hal ini disebabkan pegawai belum mampu malakukan kerjasama dengan rekan kerja saat diberikan tugas secara team. Pada indikator tanggapan anda jika mendapat benturan kepribadian dengan pegawai lain berada pada rata-rata 2,90 dengan kriteria cukup tinggi, hal ini disebabkan para pegawa belum mampu mengendalikan diri ketika menghadapi benturan kepribadian dengan rekan kerja. Kemudian pada indikator tanggapan anda saat mengalami perselisihan antar kelompok kerja berada pada rata-rata 2,92 dengan kriteria cukup tinggi, hal ini disebabkan para pegawai masih memiliki perbedaan argumen ketika bekerja dengan sesama kelompok kerja.

Secara keseluruhan dapat dilihat bahwa rekapitulasi jawaban responden mengenai konflik berada pada rata-rata 2,92 dengan kriteria jawaban cukup tinggi. Kemudian, nilai rata-rata tertinggi sebesar 2,99 pada dimensi konflik fungsional dengan indikator persaingan dalam mencapai prestasi di tempat kerja. Sedangkan nilai rata-rata terendah sebesar 2,91 berada pada dimensi konflik fungsional dengan indikator tindakan yang diberikan pegawai dalam melakukan perubahan.

\section{3) Gambaran Kineria Pegawai Pada PT PLN (Persero) P3B Sumatera UPT Pematangsiantar}

Dari hasil analisa, dapat diketahui bahwa pada dimensi spesific dengan indikator tingkat terperincinya pekerjaan berada pada nilai ratarata 4,25 dengan kriteria sangat baik, hal ini disebabkan pegawai sangat teliti ketika menyelesaikan pekerjaan yang diberikan kepadanya. Pada indikator tingkat kefokusan pada pekerjaan berada pada nilai rata-rata 4,20 dengan kriteria baik, hal ini disebabkan pegawai dituntut untuk fokus dalam bekerja. Pada indikator usaha yang dilakukan untuk mencapai tujuan berada pada nilai rata-rata 4,07 dengan kriteria baik, hal ini disebabkan pegawai telah terlebih dahulu menyusun rencana kerja yang akan dilakukan untuk mencapai tujuan.

Selanjutnya pada dimensi measurable dengan indikator tingkat target kerja yang dicapai berada pada nilai rata-rata 4,17 dengan kriteria baik, hal ini disebabkan pekerjaan yang dikerjakan pegawai dapat terselesaikan sesuai dengan target kerja. Pada indikator tingkat pengukuran hasil kerja berada pada nilai ratarata 3,99 dengan kriteria baik, hal ini disebabkan pegawai melaksanakan pekerjaannya dengan baik sehingga diperoleh ukuran hasil kerja optimal. Pada indikator penyampaian informasi ditempat kerja berada pada nilai rata-rata 4,04 dengan kriteria baik, hal ini disebabkan informasi yang ada di tempat kerja dapat tersampaikan dengan jelas dan dipahami oleh pegawai.
Untuk dimensi achievable dengan indikator tingkat pencapaian tujuan di tempat kerja berada pada nilai rata-rata 4,15 dengan kriteria baik, hal ini disebabkan sasaran pekerjaan yang diberikan kepada para pegawai dapat terlaksana. Pada indikator diskusi yang dilakukan antar rekan kerja berada pada nilai rata-rata 4,10 dengan kriteria baik, hal ini disebabkan pegawai saling berdiskusi apabila ada kendala dalam pekerjaan. Pada indikator kesepakatan kerjasama dengan rekan kerja berada pada nilai rata-rata 4,02 dengan kriteria baik, hal ini disebabkan pegawai dapat bekerjasama baik dengan rekan kerjanya.

Kemudian pada dimensi realistic dengan indikator kenyataan kondisi kerja yang ada di lapangan berada pada nilai rata-rata 4,22 dengan kriteria sangat baik, hal ini disebabkan perusahaan memberikan jaminan perlindungan K3 bagi setiap pegawai yang bekerja di lapangan. Pada indikator kompetensi yang dimiliki dalam menyelesaikan pekerjaan berada pada nilai rata-rata 4,13 dengan kriteria baik, hal ini disebabkan pegawai kompeten dalam menyelesaikan setiap pekerjaannya. Pada indikator tingkat dukungan yang diberikan kepada rekan kerja berada pada nilai rata-rata 4,24 dengan kriteria sangat baik, hal ini disebabkan para pegawai saling memberikan dukungan kerja yang positif kepada rekan kerja.

Selanjutnya pada dimensi time-bound dengan indikator tingkat efisensi waktu anda dalam menyelesaikan sesuatu pekerjaan dibanding dengan pegawai lain berada pada nilai rata-rata 4,20 dengan kriteria baik, hal ini disebabkan para pegawai bersaing secara positif untuk menyelesaikan pekerjaan mereka masing-masing. Pada indikator tingkat pencapaian bila menyelesaikan pekerjaan dengan tenggang waktu berada pada nilai ratarata 4,29 dengan kriteria sangat baik, hal ini disebabkan pegawai dalam menyelesaikan suatu pekerjaaan sesuai dengan tenggang waktu yang telah ditentukan. Pada indiktor ketepatan waktu anda hadir di tempat kerja berada pada nilai rata-rata 4,28 dengan kriteria sangat baik, hal ini disebabkan hampir seluruh pegawai datang bekerja dengan tepat waktu.

Secara keseluruhan dapat dilihat bahwa rata-rata total jawaban responden mengenai kinerja pegawai baik dari segi spesific, measurable, achievable, realistic, dan timebound mendapat nilai 4,16 dengan kriteria jawaban baik. Nilai rata-rata tertinggi sebesar 4,29 dengan kriteria jawaban sangat baik pada dimensi time-bound dengan indikator tingkat pencapaian dengan tenggang waktu. Sedangkan, untuk nilai rata-rata terendah sebesar 4,02 dengan kriteria jawaban baik pada dimensi achievablee dengan indikator kesepakatan kerjasama dengan rekan kerja.

\section{b. Deskriptif Kuantitatif}




\section{1) Regresi Linear Berganda}

Penelitian ini memiliki tujuan untuk menganalisis pengaruh stres dan konflik terhadap kinerja pegawai. Analisis data dalam penelitian ini menggunakan analisis regresi linier berganda. Analisis regresi linier berganda digunakan untuk mengetahui pengaruh variabel bebas $(X)$ dan variabel terikat $(Y)$. $X$ adalah stres, konflik dan $Y$ adalah kinerja pegawai. Analisis dijalankan dengan melakukan tabulasi jawaban responden pada kuesioner yang telah dijalankan dengan menggunakan program aplikasi SPSS sebagai berikut. Tabel 2

Hasil Regresi Linier Berganda Coefficients $^{\mathrm{a}}$

\begin{tabular}{|c|c|c|c|c|}
\hline \multirow{2}{*}{\multicolumn{2}{|c|}{$k_{n n-1}$}} & \multicolumn{2}{|c|}{ 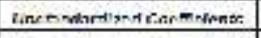 } & \multirow{2}{*}{ 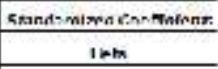 } \\
\hline & & II & $41 \mathrm{~m}$ & \\
\hline \multirow{3}{*}{1} & Bunchenil & $T \mathrm{n}_{4} \cdots$ & $a s+2$ & \\
\hline & sten: & wit & 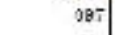 & at: \\
\hline & $\operatorname{minnax}$ & : & s. & $\therefore 4$. \\
\hline
\end{tabular}

a. Dependent Variabel: Kinerja Pegawai Sumber: hasil pengolahan data dengan SPSS versi 20

Berdasarkan hasil pengolahan data pada tabel di atas diperoleh model persamaan $\hat{Y}=$ $78,456-0,202 X_{1}-0,311 X_{2}$ diartikan bahwa terdapat pengaruh yang negatif antara variabel stres $\left(X_{1}\right)$ dan konflik $\left(X_{2}\right)$ terhadap variabel kinerja pegawai $(Y)$ pada PT PLN (Persero) P3B Sumatera UPT Pematangsiantar.

\section{2) Koefisien Korelasi dan Koefisien Determinasi}

Selanjutnya, dilakukan perhitungan korelasi berupa derajat atau kedalaman hubungan fungsional yang menjelaskan hubungan antar perubah, dinyatakan dengan yang dinamakan koefisien korelasi yang sering disimbolkan dengan $r$. Nilai $r$ dapat dihitung menggunakan SPSS versi 20. Hasil koefisien korelasi dan koefisien determinasi dapat dilihat pada tabel berikut ini:

Tabel 3

Hasil Koefisien Korelasi dan Determinasi Model Summary ${ }^{\mathrm{b}}$

\begin{tabular}{|c|c|c|c|c|}
\hline Mocel & R & I Square & Aquus:Sd R Gquse & Fiv. Eror of the [stm: \\
\hline 1 & $45 \mathrm{~s}^{3}$ & .200 & 138 & 6 \\
\hline
\end{tabular}

a. Predictors: (Constant), Stres, Konflik

b. Dependent Variabel: Kinerja Pegawai Sumber: hasil pengolahan data dengan SPSS versi 20

Berdasarkan tabel 3 diperoleh nilai korelasi $(r)=0,453$, yang artinya terdapat hubungan yang sedang antara stres, konflik, dengan kinerja pegawai pada PT PLN (Persero) P3B Sumatera UPT Pematangsiantar, sesuai dengan kriteria tingkat hubungan pada tabel 5 . Kemudian diperoleh nilai koefisien determinasi $(R)=0,206$, artinya baik tidaknya kinerja pegawai pada PT PLN (Persero) P3B Sumatera UPT Pematangsiantar sebesar $20,6 \%$ dapat dijelaskan oleh stres dan konflik, sedangkan sisanya sebesar $79,4 \%$ dapat dijelaskan oleh faktor lain seperti beban kerja, kejenuhan kerja, dukungan sosial, dan lain sebagainya.

\section{3) Uji Hipotesis}

\section{a) Uji Simultan (Uji F)}

Pengujian ini dilakukan secara simultan yaitu dilakukan untuk menentukan diterima atau ditolaknya hipotesis, pengujian hipotesis dilakukan untuk mengetahui pengaruh dari variabel stres dan konflik terhadap kinerja pegawai. Jika $F_{\text {hitung }}>F_{\text {tabel }}$ atau signifikansi $\leq$ 0,05 maka $\mathrm{H}_{0}$ ditolak. Untuk menghasilkan suatu kesimpulan yang valid, maka harus dilakukan uji hipotesis dengan menggunakan bantuan program SPSS versi 20.

$$
\text { Tabel } 4
$$

Hasil Uji Simultan (Uji F) ANOVA $^{a}$

\begin{tabular}{|c|c|c|c|c|c|c|}
\hline \multicolumn{2}{|c|}{ Mooc! } & Sum of Squs oce & of & Hean Square & + & Sip. \\
\hline & 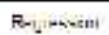 & $\mathscr{G} 2157$ & a & $315-79$ & 12,090 & $\cos t^{\circ}$ \\
\hline 1 & Fisidus & 2440.409 & 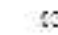 & $2: 274$ & & \\
\hline & (x)al & $30 / 6,000$ & $\mathrm{~kg}$ & & & \\
\hline
\end{tabular}

a. Dependent Variabel:Kinerja Pegawai

b. Predictors: (Constant), Konflik, Stress Sumber: hasil pengolahan data dengan SPSS versi 20

Berdasarkan tabel 4 di atas, diperoleh nilai $F_{\text {hitung }}$ sebesar $12,030>F_{\text {tabel }}(0,05 ; 2$ vs 93) dengan $\mathrm{df}=\mathrm{n}-\mathrm{k}-1 \quad(96-2-1=93)$ sebesar 3,09 , atau dengan taraf signifikan $0,000<\alpha$ 0,05 , maka $\mathrm{H}_{0}$ ditolak, artinya stres dan konflik berpengaruh negatif dan signifikan terhadap kinerja pegawai pada PT PLN (Persero) P3B Sumatera UPT Pematangsiantar.

\section{b) Uji Parsial (Uji t)}

Pengujian ini dilakukan secara parsial yaitu dilakukan untuk menentukan diterima atau ditolaknya hipotesis, pengujian hipotesis dilakukan untuk mengetahui pengaruh dari variabel stres dan konfliki terhadap kinerja pegawai. Jika $F_{\text {hitung }}>F_{\text {tabel }}$ atau signifikansi $\leq$ 0,05 maka $H_{0}$ ditolak. Untuk menghasilkan suatu kesimpulan yang valid, maka harus dilakukan uji hipotesis dengan menggunakan bantuan program SPSS versi 20. Tabel 5

Perkiraan Nilai thitung

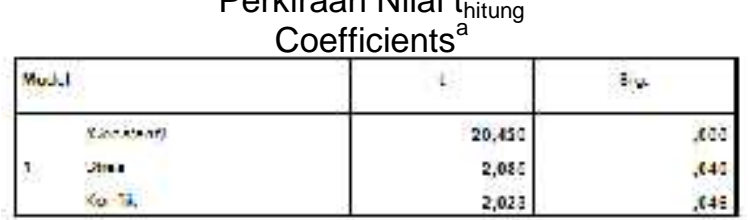

a. Dependent Variabel: Kinerja Pegawai

Sumber: hasil pengolahan data dengan SPSS versi 20

Berdasarkan tabel 5 diperoleh nilai $t_{\text {hitung }}$ pada variabel $X_{1}$ (stres) sebesar 2,085 > dari $t_{\text {tabel }}$ dengan df $=n-k-1(96-2-1)$ sebesar 1,9858 atau dengan taraf signifikan $0,040<\alpha 0,05$, maka $\mathrm{H}_{0}$ ditolak, artinya stres berpengaruh negatif dan signifikan terhadap kinerja pegawai 
pada PT PLN (Persero) P3B Sumatera UPT Pematangsiantar. Untuk variabel $\mathrm{X}_{2}$ (konflik) diperoleh nilai $t_{\text {hitung }}$ sebesar 2,023 $>$ dari $t_{\text {tabe }}$ dengan $\mathrm{df}=\mathrm{n}-\mathrm{k}-1$ (96-2-1) sebesar 1,9858 atau dengan taraf signifikan 0,046 $<\alpha 0,05$, maka $\mathrm{H}_{0}$ ditolak, artinya konflik berpengaruh negatif dan signifikan terhadap kinerja pegawai pada PT PLN (Persero) P3B Sumatera UPT Pematangsiantar.

\section{Evaluasi}

\section{a. Stres Pada PT PLN (Persero) P3B Sumatera UPT Pematangsiantar}

Berdasarkan dimensi yang digunakan dari hasil penelitian yang diperoleh dapat dijelaskan bahwa stres yang ada pada PT PLN (Persero) P3B Sumatera UPT Pematangsiantar sudah dalam kategori rendah, hal ini dapat dilihat dari berupa tuntutan tugas, tuntutan peran, tuntutan antar pribadi, struktur organisasi dan kepemimpinan organisasi. Hal tersebut dibuktikan dari nilai rata-rata keseluruhan yang dihasilkan sebesar 2,56 dengan kriteria jawaban rendah. Namun masih ada beberapa aspek-aspek walaupun sudah dalam kriteria rendah tetapi masih diatas nilai rata-rata.

Pertama pada dimensi tuntutan tugas dengan indikator keadaan kondisi kerja memperoleh nilai rata-rata 2,58 dengan kriteria jawaban rendah, cara mengatasi hal tersebut adalah sebaiknya perusahaan menyediakan fasilitas yang lebih memadai lagi agar tercipta kondisi kerja yang baik bagi para pegawai. Kemudian pada indikator tata letak kerja fisik memperoleh nilai rata-rata 2,64 dengan kriteria cukup tinggi, cara untuk mengatasi hal tersebut sebaiknya perusahaan memperluas ruang gerak bagi para pegawai.

Untuk dimensi tuntutan peran dengan indikator sikap dalam melakukan peran ganda memperoleh nilai rata-rata 2,60 dengan kriteria jawaban rendah, cara mengatasi hal tersebut adalah sebaiknya pimpinan memberikan kesempatan kepada para pegawai untuk membiasakan diri melakukan peran ganda di tempat kerja. Kemudian pada indikator kesanggupan menyelesaikan pekerjaan yang kurang sesuai mendapat nilai rata-rata 2,57 dengan kriteria jawaban rendah, cara untuk mengatasi hal tersebut adalah sebaiknya pegawai dibekali pengetahuan dan pelatihan sehingga mampu berprestasi di tempat kerja.

Selanjutnya pada dimensi tuntutan antar pribadi dengan indikator tingkat dukungan sosial mendapat nilai rata-rata 2,63 dengan kriteria cukup tinggi, cara untuk mengatasi hal tersebut adalah sebaiknya setiap pegawai meningkatkan rasa kepeduliannya terhadap sesama rekan kerja. Kemudian pada dimensi struktur organisasi dengan indikator tingkat peraturan yang ada di tempat kerja memperoleh nilai rata-rata 2,58 dengan kriteria jawaban rendah, cara untuk mengatasi hal ini sebaiknya pimpinan bersikap lebih tegas supaya para pegawai mematuhi peraturan perusahaan. Kemudian pada indikator sistem pengambilan keputusan di tempat kerja mendapat nilai 2,57 dengan kriteria jawaban rendah, cara mengatasi hal ini sebaiknya pimpinan menghargai setiap masukan maupun pendapat dari para pegawai.

Untuk dimensi kepemimpinan dengan indikator gaya kepemimpinan mendapat nilai rata-rata 2,58 dengan kriteria jawaban rendah, cara mengatasi hal ini sebaiknya pimpinan lebih bersifat terbuka melalui gaya kepemimpinanya. Kemudian pada indikator kepedulian terhadap pegawai baru memperoleh nilai rata-rata 2,61 dengan kriteria jawaban cukup tinggi, cara mengatasi hal ini sebaiknya pegawai lama meningkatkan rasa sosialisasi terhadap pegawai baru. Pada indikator kemampuan memimpin rapat saat diperlukan berada pada nilai rata-rata 2,68 dengan kriteria jawaban cukup tinggi, cara mengatasi hal ini sebaiknya pimpinan mengajarkan cara memimpin rapat kepada pegawai.

\section{b. Konflik Pada PT PLN (Persero) P3B Sumatera UPT Pematangsiantar}

Konflik merupakan segala macam interaksi pertentangan atau antagonistic antar dua orang atau lebih di dalam perusahaan. Berdasarkan hasil penelitian yang diperoleh dapat dijelaskan bahwa konflik berada pada kategori tinggi, hal ini dapat dilihat dari dimensi konflik fungsional dan disfungsional berada pada nilai rata-rata 2,92 dengan kriteria cukup tinggi. Namun, masih ada beberapa aspekaspek walaupun sudah dalam kriteria cukup tinggi tetapi masih diatas nilai rata-rata.

Pada dimensi konflik fungsional dengan indikator tingkat persaingan dalam meraih prestasi mendapat nilai rata-rata 2,99 dengan kriteria jawaban cukup tinggi, cara untuk mengatasi hal ini adalah sebaiknya para pegawai melakukan persaingan secara sehat untuk meraih prestasi kerja.

\section{c. Kinerja Pegawai Pada PT PLN (Persero) P3B Sumatera UPT Pematangsiantar}

Kinerja merupakan gambaran mengenai tingkat pencapaian pelaksanaan suatu kegiatan dalam mewujudkan sasaran, tujuan, visi, dan misi organisasi yang tertuang dalam strategic planning suatu organisasi. Dimensi kinerja pegawai pada PT PLN (Persero) P3B Sumatera UPT Pematangsiantar dikatakan sangat baik, hal ini dapat dilihat dari hasil kuesioner yang dibagi kepada responden secara keseluruhan memperoleh nilai rata-rata sebesar 4,16. Berdasarkan nilai rata-rata di atas, terdapat beberapa dimensi walaupun sudah dalam kriteria baik tetapi masih dibawah nilai rata-rata. 
Pertama pada dimensi spesific dengan indikator usaha yang dilakukan untuk mencapai tujuan berada pada nilai rata-rata 4,07 dengan kriteria baik, cara untuk mengatasi hal tersebut sebaiknya pegawai mengeluarkan semua potensinya dalam merealisasikan tujuan perusahaan. Kemudian pada dimensi measurable dengan indikator penyampaian informasi di tempat kerja berada pada nilai ratarata 4,06 dengan kriteria baik, cara untuk mengatasi hal tersebut sebaiknya komunikasi di tempat kerja dapat terjalin dengan baik.

Pada dimensi achievable dengan indikator tingkat pencapaian tujuan di tempat kerja berada pada nilai rata-rata 4,15 dengan kriteria baik, cara untuk mengatasi hal tersebut sebaiknya pegawai bertanggungjawab terhadap sasaran kerja yang hendak dicapai. Pada indikator diskusi yang dilakukan antar rekan kerja berada pada nilai rata-rata 4,10 dengan kriteria baik, cara mengatasi hal tersebut sebaiknya para pegawai saling membina hubungan kerja yang baik dengan sesama rekan kerja. Kemudian pada indikator kesepakatan kerjasama anda dengan rekan kerja berada pada nilai rata-rata 4,02 dengan kriteria baik, cara mengatasi hal tersebut sebaiknya pegawai saling sepakat dan bekerjasama dalam menyelesaikan suatu pekerjaan.

Pada dimensi realistic dengan indikator kompetensi yang dimiliki dalam menyelesaikan pekerjaan berada pada nilai rata-rata 4,13 dengan kriteria baik, cara mengatasi hal tersebut sebaiknya perusahaan meningkatkan kompetensi para pegawai dengan mengikutsertakan pegawai dalam pendidikan dan pelatihan kerja.

\section{KESIMPULAN DAN SARAN}

\section{Kesimpulan}

a. Hasil analisis deskriptif kualitatif tentang stres berdasarkan dimensi tuntutan tugas, tuntutan peran, tuntutan antar pribadi, struktur organisasi, dan kepemimpinan memperoleh nilai rata-rata jawaban keseluruhan sebesar 2,56 dengan kriteria rendah. Kemudian nilai rata-rata tertinggi sebesar 2,68 dengan kriteria nilai cukup tinggi pada dimensi kepemimpinan dengan indikator kemampuan dalam memimpin rapat saat diperlukan. Sedangkan nilai rata-rata terendah sebesar 2,46 dengan kriteria rendah pada dimensi struktur organisasi dengan indikator tingkat penentuan diferensiasi struktur organisasi di tempat kerja.

b. Hasil analisis deskriptif kualitatif tentang konflik berdasarkan dimensi konflik fungsional dan konflik disfungsional memperoleh nilai rata-rata jawaban keseluruhan sebesar 2,92 dengan kriteria jawaban cukup tinggi. Kemudian nilai rata- rata tertinggi sebesar 2,99 dengan kriteria cukup tinggi pada dimensi konflik fungsional dengan indikator persaingan dalam mencapai prestasi di tempat kerja. Sedangkan nilai rata-rata terendah sebesar 2,90 dengan kriteria jawaban cukup tinggi berada pada dimensi konflik fungsional dengan indikator tindakan yang diberikan pegawai dalam melakukan perubahan.

c. Hasil analisis deskriptif kualitatif tentang kinerja pegawai berdasarkan dimensi spesific, measurable, achievable, realistic, dan time-bound memperoleh nilai rata-rata jawaban keseluruhan sebesar 4,16 dengan kriteria jawaban baik. Kemudian nilai ratarata tertinggi sebesar 4,29 dengan kriteria jawaban sangat baik pada dimensi timebound dengan indikator tingkat pencapaian menyelesaikan pekerjaan dengan tenggang waktu. Sedangkan nilai rata-rata terendah sebesar 4,02 dengan kriteria jawaban baik pada dimensi achievable dengan indikator kesepakatan kerjasama dengan rekan kerja.

d. Hasil analisis regresi linear berganda diperoleh persamaan sebagai berikut $\hat{Y}=$ $78,456-0,202 X_{1}-0,311 X_{2}$ artinya terdapat pengaruh yang negatif antara variabel stres $\left(X_{1}\right)$ dan konflik $\left(X_{2}\right)$ terhadap variabel kinerja pegawai (Y) pada PT PLN (Persero) P3B Sumatera UPT Pematangsiantar.

e. Hasil analisis korelasi diperoleh nilai $r=$ 0,453 , yang artinya terdapat hubungan yang sedang dan negatif antara stres, konflik, dan kinerja pegawai pada PT PLN (Persero) P3B Sumatera UPT Pematangsiantar. Kemudian, diperoleh nilai koefisien determinasi $(R)=$ 0,206 , artinya baik tidaknya kinerja pegawai pada PT PLN (Persero) P3B Sumatera UPT Pematangsiantar sebesar $20,6 \%$ dapat dijelaskan oleh stres dan konflik, sedangkan sisanya sebesar $79,4 \%$ dapat dijelaskan oleh faktor lain seperti: beban kerja, kejenuhan kerja, dukungan sosial, dan lain sebagainya.

f. Hasil uji hipotesis secara simultan dalam uji $F$, diperoleh nilai $F_{\text {hitung }}$ sebesar $12,030>$ $\mathrm{F}_{\text {tabel }}(0,05 ; 2$ vs 93$)$ dengan df $=\mathrm{n}-\mathrm{k}-1$ (962-1=93) sebesar 3,09, atau dengan taraf signifikan $0,000<\alpha 0,05$, maka $\mathrm{H}_{0}$ ditolak, artinya stres dan konflik berpengaruh negatif dan signifikan terhadap kinerja pegawai pada PT PLN (Persero) P3B Sumatera UPT Pematangsiantar secara simultan.

g. Hasil uji hipotesis secara parsial dalam uji t, diperoleh nilai $t_{\text {hitung }}$ pada variabel stres $\left(X_{1}\right)$ sebesar 2,085 $>$ dari $t_{\text {tabel }}$ dengan $d f=n-k-1$ (96-2-1) sebesar 1,9858 atau dengan taraf signifikan $0,040 \leq \alpha \quad 0,05$, maka $\mathrm{H}_{0}$ ditolak, artinya stres berpengaruh negatif dan signifikan terhadap kinerja pegawai pada PT PLN (Persero) P3B Sumatera UPT Pematangsiantar. Sedangkan untuk variabel konflik $\left(\mathrm{X}_{2}\right)$ diperoleh nilai $\mathrm{t}_{\text {hitung }}$ sebesar $2,023>$ dari $t_{\text {tabel }}$ dengan $d f=n-k-1(96-2-1)$ 
sebesar 1,9858 atau dengan taraf signifikan $0,046 \leq \alpha \quad 0,05$, maka $H_{0}$ ditolak, artinya konflik berpengaruh negatif dan signifikan terhadap kinerja pegawai pada PT PLN (Persero) P3B Sumatera UPT Pematangsiantar.

\section{Saran}

a. Stres yang ada pada PT PLN (Persero) P3B Sumatera UPT Pematangsiantar dapat dikelola dengan baik, sebaiknya perusahaan menyediakan fasilitas yang lebih memadai agar tercipta kondisi kerja yang baik bagi para pegawai, pegawai meningkatkan rasa kepeduliannya terhadap sesama rekan kerja dan pimpinan bersikap lebih tegas supaya pegawai mematuhi peraturan perusahaan.

b. Konflik yang ada pada PT PLN (Persero) P3B Sumatera UPT Pematangsiantar dapat dikelola dengan baik, sebaiknya para pegawai melakukan persaingan secara sehat untuk meraih prestasi kerja.

c. Kinerja pegawai yang ada pada PT PLN (Persero) P3B Sumatera UPT Pematangsiantar dapat menghasilkan kinerja yang optimal, sebaiknya pegawai mengeluarkan semua potensinya dalam merealisasikan tujuan perusahaan, dan pegawai saling sepakat dan bekerjasama dalam menyelesaikan suatu pekerjaan.

\section{E. DAFTAR PUSTAKA}

Dessler, Gary. 2007. Manajemen Sumber Daya Manusia. Edisi Ketiga. Jakarta: Erlangga.

Luthans, Fred. 2006. Perilaku Organisasi, Edisi 10. Yogyakarta: Andi.

Mangkunegara, Anwar Prabu AA. 2001. Manajemen Sumber Daya Manusia Untuk Perusahaan. Bandung: Remaja Rosdakarya.

Mathis, Robert L dan John H Jackson. 2006. Manajemen Sumber Daya Manusia, Edisi Kesepuluh. Jakarta: Salemba Empat.

Mondy,Wayne. 2008, Manajemen Sumber Daya Manusia. Jakarta: Erlangga.

Robbins, Stephen P. 2006. Prinsip-prinsip Organisasi. Jakarta: PT Erlangga.

Robbins, Stephen P. 2008. Perilaku Organisasi, Edisi 10. Jakarta: PT Index.

Robbins, Stephen $\mathrm{P}$ dan Timothy A Judge. 2008. Organizational Behaviour. New Jersey: Prentice Hall.

Wahyudi. 2011. Manajemen Konflik Dalam Organisasi, Cetakan IV. Bandung: Alfabeta. 